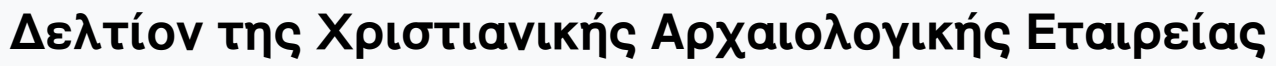

Tó 10 (1981)

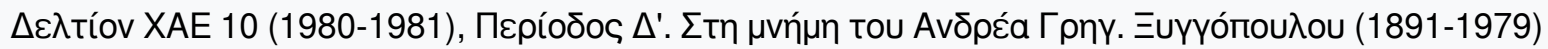

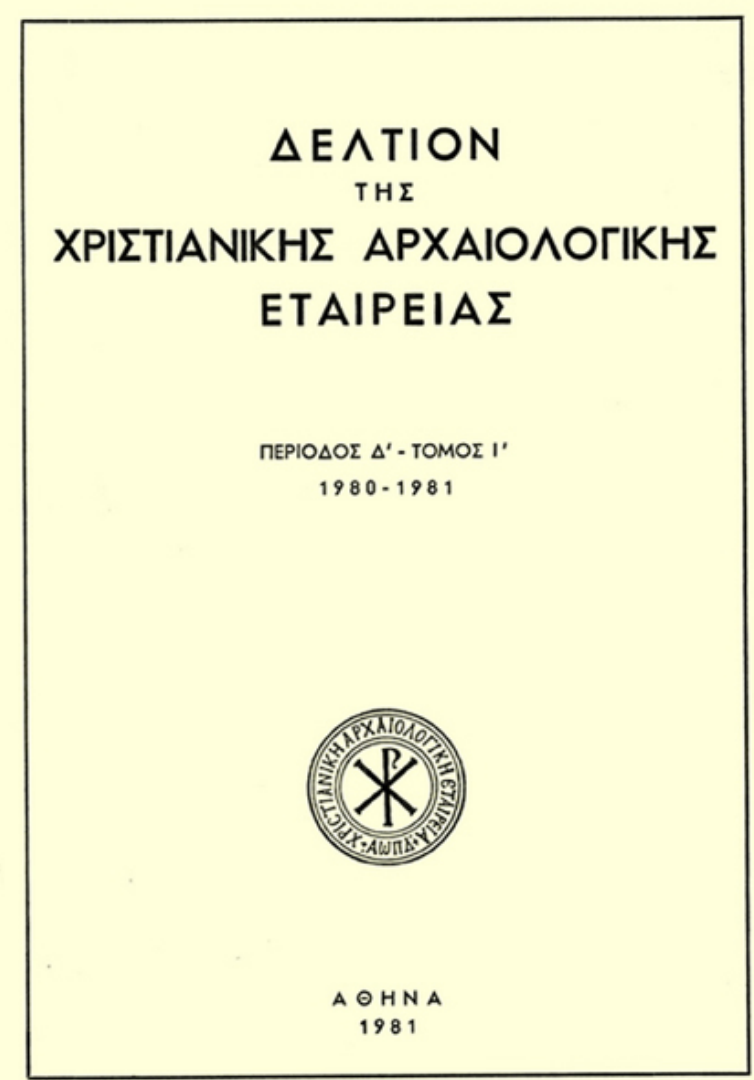

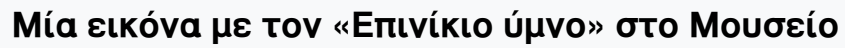
Mrevákn (rív. 11-12)

George GALAVARIS

doi: $10.12681 /$ dchae.899

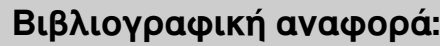

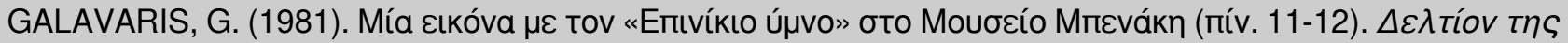

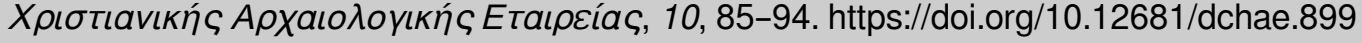




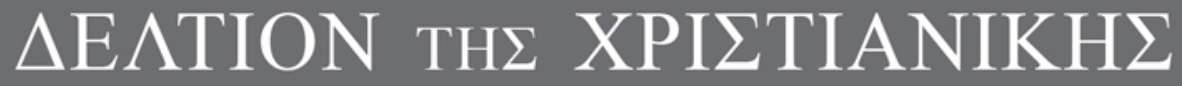 APXAIO $\Lambda$ OГIKH $\Sigma$ ETAIPEIA $\Sigma$}

An Icon with the "Epinikios" Hymn in the Benaki Museum (pl. 11-12)

George GALAVARIS

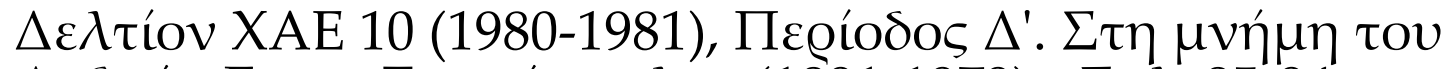

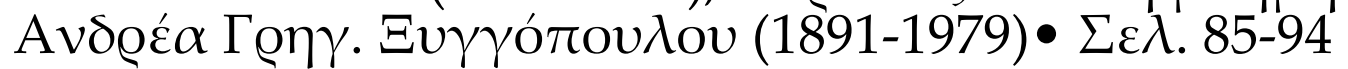

A@HNA 1981 


\section{AN ICON WITH THE "EPINIKIOS" HYMN IN THE BENAKI MUSEUM}

(Pl. 11 - 12)

The publication of the Catalogue of Icons in the Benaki Museum by Andreas Xyngopoulos in 1936 constituted a landmark for the study of icons. Not-withstanding the subsequent, splendid contributions which have been made to this field by Xyngopoulos himself and other scholars, this book has remained a fundamental one. It is then appropriate in this short paper, offered to the memory of a great scholar, to return to one of the Benaki icons, icon inv. no. 3011, and to reconsider its theme ${ }^{1}$.

The icon has been described fully by Xyngopoulos. For the purposes of our discussion here, we describe the main elements of the composition. The icon represents the "New Testament" or "Western" Trinity, a type not known on icons before the fall of Constantinople, and which portrays all Three Persons (Pl. 11a). Christ holding an open gospel with a text, no longer readable, sits to the right of the Father, represented as the Ancient of Days, with an open scroll in His left hand the text of which refers to the relation of the Son to the Father (Mt. 3:17 and Mk. 9:7). Both are seated on three, six-winged seraphs, resting their feet on winged wheels representing the Thrones in the hierarchy of angels. A fourth seraph is below in the centre, between the feet of Christ and the Ancient of Days. This seraph holds two open scrolls, one at each hand, containing the text of the Epinikios Hymn, otherwise known as the Seraphic Hymn which is transcribed here as it appears on the icon: $\tilde{\alpha} \gamma$ lo $\tilde{\alpha}^{\alpha} \gamma$ to

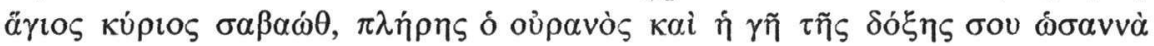

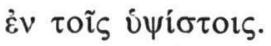

Above, between the Father and the Son, is the Holy Ghost in the form of a dove, depicted within a glory consisting of two superimposed lozenges. The Trinity and the seraphs are set in an oval mandorla carried by the Four Apocalyptic Creatures or Zodia which are winged, nimbed and holding gospels; they are, therefore, identified with the evangelists.

1. Andreas Xyngopoulos, Katalogos ton Eikonon, Mouseion Benaki, Athens, 1936, no 40. 
Depicted on the corners of the icon, their names are inscribed in the usual abbreviated form. While the names of Mark and Luke have survived, those that accompanied the eagle and the angel are no longer visible. The identification of the symbols with specific evangelists follows the order of Epiphanios, not the only one to be found in the Christian East; the symbols are to be read from left to right counterclockwise, their arrangement recalling the concentric movement described in the Vision of the Prophet Ezekiel $(1: 1 \mathrm{ff})^{2}$. An inscription on the lower left part of the glory, just above the lion, symbol of Mark, ascribes the icon to Ioannis Moscos, known also from other works (end of seventeenthbeginning eighteenth century), and gives the date 1702. The icon has suffered flaking in the area of the Holy Ghost and along the left-hand side of the mandorla.

The icon has been recently cleaned and a photograph, kindly supplied by the Benaki Museum, has revealed some new elements. On the mandorla enclosing the Trinity and under the present gold leaf there are fragments of an inscription in beautiful, majuscule letters, beginning from the seraph at the right knee of Christ and concluding on the opposite part of the glory, at the point where the right-hand scroll of the seraph, containing the Epinikios, ends, just above the calf, symbol of Luke. While the letters of the inscription can be seen on the photograph, probably the result of the use of a sensitive film, they cannot be discerned with one's bare eye on the actual icon. This would mean that the icon was restored sometime and that the inscription was covered on the occasion, possibly because it was not fully readable by that time. It was not possible to obtain infrared photos and I can only present here the results of microphotography attempted from the photo at my disposal at the laboratories of McGill University.

The first part of the inscription (left side) is almost completely destroyed except the following letters which, I think, I discern : - - - - - MOФ - . - - MN - . . . E E - - $\Theta$ - - EH - - E - - - B -. More letters have been preserved on the opposite side, above the Ancient of Days, which, however, do not enable me to decipher the inscription. I cite here whatever I think I read in the hope that proper photographic investigation in the future will make the deciphering and completion of the inscription possible: - - HKA - - - MEG(I ?)C MIA AY(TOY?) ФYCIN (K)E APX - . - O - - K(E?)TMHTOG (P1. 12a). The words read would imply that

2. For the symbols and the various orders see, G e orge Gal avaris, The Illustrations of the Prefaces in Byzantine Gospels (Byzantina Vindobonensia, XI), Vienna, 1979, pp. 36ff. 
the inscription made, perhaps, a reference to the Holy Trinity. However that may be, it is certain that palaeographically the inscription is identical to that giving the name of the artist and the date of the icon. This means that, in our opinion, there can be no question as to the authenticity of the authorship of the icon. But apart from the "signature" and considering the artistic uneveness of the work of Moscos, already pointed out by Xyngopoulos in another important publication ${ }^{3}$, stylistic comparisons with an icon of the Crucifixion, now in Venice in the Collection of the Hellenic Institute, published by Chatzidakis, dating from the year 1711, confirm the hand of the master ${ }^{4}$. For instance, the head of John kneeling by the cross is rendered in the same manner as the head of the angel, symbol of Matthew, in the Benaki icon.

Xyngopoulos related the theme of the icon to the Vision of Isaiah on the one hand and accredited Moscos with a certain originality on the other, by ascribing the addition of the symbols of the evangelists to the artist. Recent research and publications of post-byzantine icons have thrown more light on the theme of the icon and a reconsideration is justified all the more since in the realm of post-Byzantine art we are still faced with many problems, among which questions of iconography and transmission of images occupy a special place.

The theme cannot be exclusively related to the Vision of Isaiah (6:1-3) which specifies that "The Lord sitting on a high and exalted throne" was surrounded by seraphs. "And seraphs stood round about him: each one had six wings; and with the two they covered their faces, and with the two they covered their feet, and with the two they flew." This text explains part of the composition. For the other elements and above all the Zodia or the Four Apocalyptic Creatures, we must go to the Vision of Ezekiel (1:1ff.)

The texts of the two visions belong to the so-called apocalyptic literature. Very early their original illustrations lost their dependence on these texts; they migrated to other texts, underwent adaptations and suffered conflations like the one manifested in the icon. We can cite at least one example of the migration of one of the visions to other texts. The so-called Vision of Isaiah which accompanies the prayer of

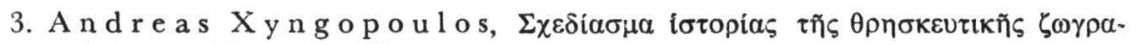

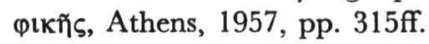

4. Ma nolis Ghatzidakis, Icônes de Saint-Georges des Grecs et de la collection de l'Institut hellénique de Venise, Venice, 1962, pl. 72, no. 160, and Icônes grecques à Venise, Album, Venice, 1975, pl. 72, fig. 160. 
Isaiah in a Psalter, now in Athens, Bibl. Nat. cod. 7, fol. $143 \mathrm{v}$, is in fact an abbreviated form of the Vision of Ezekiel ${ }^{5}$.

The interchange and conflation of the two visions was brought about by the Early Ghristian Fathers and found a place in the Liturgy in the prayer of the Trisagion in the Mass of the Gatechumens and in the Eucharistic prayer in the Anaphora - the prayer of praise and thanksgiving - which includes the full text of the Seraphic Hymn sung by the people in reply to the prayer recited by the priest silently. The hymn concludes the first part of the Thanksgiving. It is the fuller text of this Hymn which, inscribed on the scroll held by the seraph on the icon, elucidates the theme. This is not simply a representation of the Holy Trinity but a pictorialization of the Seraphic Hymn related to the Eucharistic prayer of the Anaphora. It can further be said that the hymn is addressed to the Holy Trinity.

All iconographic elements belong to this theme which has had a long tradition in Christian art. The Four Zodia, identified with the symbols of the evangelists, became essential components of Theophanic representations, Majestas compositions, which never left Byzantine art, whether in monumental representations or book illumination and icons. One of the earliest examples in monumental compositions is provided by the apse mosaic of the Church of Hosios David in Thessalonike, first published by Xyngopoulos ${ }^{6}$. In manuscript illuminations, a particular form of Majestas pictorializing the Seraphic hymn is found in the illus-

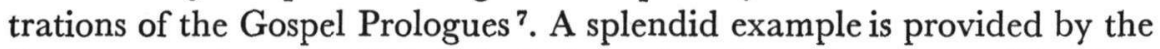
Parma gospels, cod. Bibl. Pal. 5, from the eleventh century (Pl. 12b). In monumental examples and in Prologue-illustrations the Living Creatures came to be identified with the four evangelists and with the seraphim and cherubim who sing the Seraphic Hymn. The Benaki icon derives from this tradition and the Four Zodia, therefore, are not additions of this particular icon painter.

What, however, distinguishes the Benaki icon from the Byzantine examples is the representation of the Trinity in the theme of the Se-

5. See, Byzantine Art an European Art (Ninth Exhibition Council of Europe), Athens, 1964, no. 295; for transmission of these illustrations in other texts and subsequent adaptations, see George Galavaris, The Illustrations of the Liturgical Homilies of Gregory Nazianzenus, Princeton, 1969, pp. 120ff; for the vision of Ezekiel in general see W. Ne u s s, Das Buch Ezeckiel in Theologie und Kunst, Munich, 1912.

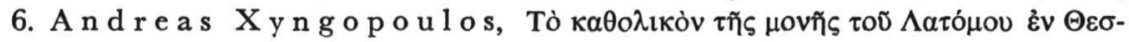

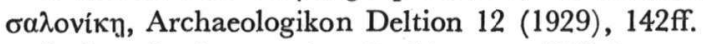

7. See G a l a va ris, Prefaces, pp. 73ff, for an extensive discussion of the subject. 
raphic Hymn which is not found in early compositions. It is this element which deserves to be considered further.

The Thanksgiving prayer makes reference to the Holy Trinity and it can be assumed that an artist familiar with the Liturgy can modify an existing composition and introduce a new element. This remains a possibility. Nevertheless the power of tradition may have been stronger than an inspiration deriving from the Liturgy. This may be the case of the present icon. We are led to this thought because in Byzantine art there are two iconographic trends which point to the eventual introduction of the Trinity in the theme of the Seraphic Hymn. In the Prologue-illustrations in Byzantine gospels, associated with the Epinikios Hymn, references to the Trinity were alluded to by inscriptions, like the one, for example, found in a gospel book in Venice, cod. Marc. $\mathrm{Z} 540$, or they were pictorialized by the three different colour-tones of the glory of Christ, or by representations of Christ's three "manifestations" Christ Pantocrator, Christ as the Ancient of Days and Emanuel, at times found in one and the same example, for instance, in a seventh century icon in the Monastery of St Catherine in Sinai and in the cod. Paris. gr. 74, to mention two examples only. In the Paris gospel the Seraphic Hymn is spread out in more than one miniature ${ }^{8}$.

The other iconographic tradition is the representation of the Trinity itself in Byzantine art. Known in the form of the Synthronoi, Paternitas, and the "New Testament" type, representations of the Trinity contain elements taken from the prophetic visions, such as the celestical powers, for example, but they have not been associated with the Four Zodia whose presence gives a direct reference to the Seraphic Hymn ${ }^{9}$. This practice of Byzantine artists is different from that followed by Western Medieval artists. In the West the Trinity was associated with the Four Apocalyptic Creatures already since the twelfth century in a composition known as the Throne of Grace (Gnadenstuhl), an association extended to the New Testament Trinity later ${ }^{10}$. An incomplete attempt for a similar association is presented by a late Byzantine example, the fourteenth century Serbian Psalter in Munich. The artist has introduced

8. Ibid. pp. 93ff, 100ff; K. W e i t z m a n n, The Monastery of St Catherine at Mount Sinai. The Icons, Vol. I: From the Sixth to the Tenth c., Princeton, N. J., 1976, no 168.

9. H a ns Gerstinger, Úber Herkunft und Entwicklung der anthropomorphen byzantinisch-slawischen Trinitätsdarstellungen des so-genannten Synthronoiund Paternitas (Otécestvo) Typus, Festschrift W. Sa-Zaloziecky, Graz, 1956, pp. 79 - 85.

10. W. B r a u n f e l s, Die Heilige Dreifaltigkeit, Düsseldorf, 1974, fig. 38 (French miniature c. 1120 in Cambrai) and fig. 33 (French miniature c. 1380, in Berlin). 
the following miniature as an illustration for Psalm 76, verses 2, 3: A medallion, inscribed within a rectangle, encloses a bust of the Ancient of Days on whose breast is another smaller bust of Christ Emmanuel. On the four corners of the rectangle are the Four Apocalyptic Creatures holding gospels. Left and right, on the frame of the composition are two, possibly, seraphim ${ }^{11}$. This illustration has not a direct relation to the text of the Psalm with which it is physically related or to the Vision of Isaiah, as the first student of this manuscript thought. It is not within the scope of our paper to discuss the reasons that determined the choice of this miniature, for we are concerned with its compositional elements whose sources are clear. They go back to the theme of the Seraphic Hymn. But instead of Christ Pantocrator or the Ancient of Days or Christ Emmanuel, the artist has borrowed the figures of Father and Son from a Paternitas composition ${ }^{12}$. The Holy Ghost has not been included. In the Belgrade copy of this Psalter there appears a similar illustration including, however, Christ Pantocrator only, which means that this miniature remains faithful to traditional representations of the Eucharistic prayer ${ }^{13}$. Nevertheless the Munich miniature forms another step towards the introduction of the Trinity to the theme which we are discussing.

In the light of all this, it is obvious that the Benaki icon reflects these Byzantine traditions and carries them further by introducing the Trinity in the representation of the Epinikios Hymn. In representing the Trinity, Moscos followed the New Testament type which had become common in icons by the end of the seventeenth century.

From the pictorial tradition of the same period stems also the concept of the association of the Seraph with the unfolding scroll containing the text of the hymn. It is found in seventeenth-century illustrated liturgies, as we see in a manuscript of the Four Liturgies in the monastery of Iviron, Lit. V (1438) from the year 1659. On fol. 24v the initial T which introduces the Seraphic Hymn, the Four Creatures are shown in the

11. Josef Strzygowski, Die Miniaturen des serbischen Psalters (Denkschriften der kaiserlichen Akademie in Wien, LII), Vienna, 1906, p. 45, pl. XXV, 55.

12. See above, n. 9.

13. St r z y g owski, op. cit., loc. cit. Concerning the representation of the Trinity found in the same psalter, it is interesting to note that the Belgrade manuscript has preserved a better version. In the Munich copy, fol. 146v, Ps. 109:1, Father and Son are on a throne but the Holy Ghost in the form of a dove is held by Christ who sits to the left of the Father. The illustration is not well preserved but the composition and figures are identifiable. In the Belgrade copy, fol. 189r, Christ sits to the right of the Father with the Holy Ghost above them. Ibid., pl. XXXVII, and p. 57, fig. 26. 
act of singing ${ }^{14}$. The scroll with the text of the hymn unfolds around the stem of the initial. In general, the motif of angels holding scrolls with texts is seen also in icons of the same period as at least two icons by Theodore Poulakis (1622 - 1692), now in Patmos, demonstrate ${ }^{15}$.

This element is common in Italian art and since the fifteenth century it is popular in Venice as, for example, the work of the Vivarini shows. Among other works there is a Crucifixion panel by Antonio and Giovanni d'Alemagna, now in the National Gallery of Prague, depicting the symbols of the evangelists above the cross holding open, inscribed scrolls. While in the Coronation of the Virgin by the same artists (1444) now in Venice, Church of St Pantaleon, inscribed scrolls are held by angels ${ }^{16}$. It is most likely that such western works provided the motif or the concept of it to Greek masters.

The question, however, must be raised whether it was indeed Moscos who first brought about the pictorial association of the New Testament Trinity and the Seraphic Hymn. At present the question cannot be answered for large collections of post-Byzantine icons are still unpublished. But, until the relevant material becomes available so me suggestions can be made.

The liturgical theophany in its more common, abbreviated form, known as Christ in Glory, showing Christ seated on or carried by the Four Apocalyptic Creatures, continues to appear in Greek, post-Byzantine icons ${ }^{17}$ and it is popular in Russian icons some of which continue to reflect in the order of the symbols other traditions than that of Epiphanios, known throughout Byzantine art ${ }^{18}$. Following the earlier Byzantine tradition referred to above, Greek icon painters chose different types of

14. Discussed and reproduced in G a l a v a r is, Prefaces, pp. 85ff, fig. 72 .

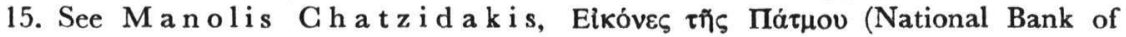
Greece), Athens, 1977, nos 149, 150.

16. See, Rodolfo Palluchini, I Vivarini (Antonio, Bartolomeo, Alvise), Venice n.d., figs 45, 58 and several others. The examples are indeed numerous. This motif, which should not be confused with that of the Prophets or Saints holding inscribed scrolls, had a great popularity and is found also in seventeenth-century icons from Poland. See Ikonen aus Polen, Ikonenmuseum Recklinghausen, Exhibition Catalogue, Recklinghausen, 1966, no 27.

17. See, for example, icon by Emmanuel Tzanès in the Byzantine Museum, Athens, reproduced in $\mathrm{Karoline} \mathrm{Kreidl}-\mathrm{Pap}$ ado pulos, Die Ikonen im Kunsthistorischen Museum in Wien, Jahrbuch der Kunsthistorischen Sammlungen in Wien, 66 (1970), p. 98f., fig. 74.

18. See, for instance, a seventeenth century Russian icon in Echteld, Holland (Institute for Icon-Art) no. 3417, in which the eagle is identified with the evangelist Mark and the lion with John in accordance with one of the olders orders that of Ire- 
Christ. One that was greatly disseminated in seventeenth-century and later Majestas compositions was that of Christ as the Great Archpriest. Attention to the origins and the liturgical connotations of this theme has already been drawn by scholars, although a complete study of the theme it still to be undertaken ${ }^{19}$. The dogmatic truth concerning Christ's priesthood is beautifully expressed in the silent prayer of the Great Entrance recited by the priest during the singing of the Cherubikon. Christ is the one who is offered and the one who is offering. $\mathrm{He}$ is the actual priest offering the Divine Liturgy, a truth aparent throughout the Liturgy but stressed in the Eucharistic prayer before the consecration of the gifts. The words of Consecration are pronounced by the priest in the first person. So at this moment Christ the eternal priest, speaks through the mouth of the priest. Since early Christian times Christ's priesthood has been pictorialized in scenes like the Communion of the Apostles, which have continued to appear in post-Byzantine icons. In many of them the role of Christ as a priest is stressed by the priestly vestments which he wears ${ }^{20}$.

However, compositions on icons portraying Christ in Glory, in which Christ is represented as King of Kings and Great Archpriest can be more specifically interpreted as images which relate the Seraphic Hymn to the second part of the Eucharistic prayer. For such icons show not only the triumphant appearance of Christ in the resounding sounds of the Seraphic hymn but they constitute also a reference to the Consecration, which in the Liturgy follows the Hymn, because Christ is about to offer himself. This is why in so many examples the text on the gospel held by Christ, the Great Archpriest, reads: "Take, eat, this is my body. .."21. These are Christ's words of Consecration which are repeated by the priest. In some icons with this theme the relation to the Eucha-

naios; also another example in the same collection, published by $\mathrm{H}$ e t t y J. R o o z emond-van Ginhoven, Ikon Inspired Art, Echteld, 1980, no. 82 (also in German and Dutch); see G a l a va r is, Prefaces, pp. 17, 18, 36ff.

19. See Mirja nn a T a tić-D ju rić, Icône signée de Constantino Zgouros, avec la represéntation du Christ Grand Archevêque, Praktika A' Diethnous Synedriou Peloponnesiakon Spoudon, 2, Athens, 1976, $211-218$ with excellent bibliography; also $\mathrm{Ch}$ atzidakis, Patmos, no 15 .

20. See L. H. Grondys, Croyances, doctrines et iconographie de la liturgie céleste, trône de grâce et le Christ prêtre officiant, Mélanges d'archéologie et d'histoire 74 (1962), 665 - 703.

21. The examples are numerous. See, for instance, icon by Victor in the Museum of Zakynthos and another one by Kallergi (A.D. 1723) also in Zakynthos. Also several examples among the post-Byzantine icons in Sinai, unpublished, one of which, in the 
ristic prayer is made more manifest with the inclusion of prophets. For example in an eighteenth-century icon in the Lomberdos collection (N.

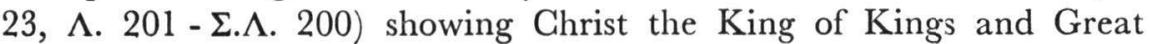
Archpriest "seated on the cherubim" with the four creatures holding gospels, their names inscribed, the painter has represented on the throne three prophets, two of whom, David and Solomon are related to the Incarnation. The choice of the text on the gospel of Christ "My kingdom is not of this world. . This is the bread which came down from heaven" (Jh 18:36, Jh 6:58) refers both to the Epiphany of Christ as the King of Kings and to the Consecration ${ }^{22}$. The inclusion of the prophets echoes once more the tradition of the liturgical Majestas depicted in the domes of Byzantine churches and in the illustrated Prologues of Byzantine gospels ${ }^{23}$.

In touching upon some aspects of the theme of Christ as King of Kings and Great Archpriest, I have tried to suggest the contribution of the Anaphora of the Liturgy to post-Byzantine icon themes and within this context to understand better the importance of the Benaki icon. While the "Archpriest" relates the Epiphany of Christ to the Consecration, the Benaki icon focus on the Seraphic Hymn, on the hymn of glory offered by the entire creation to the Creator, "Father, Son and Holy Ghost." Among icons of the post-Byzantine period the representation seems to be unique. And yet this not quite so, for at least one more relative is known to me. This is an icon in the collection of Dr S. AmbergHerzog, in Kölliken, Switzerland, representing the New Testament Trinity accompanied by the symbols of the evangelists, angels, cherubim, thronoi, the sun and the moon $(\mathrm{Pl} .11 \mathrm{~b})^{24}$. In its composition the icon is not exactly identical with the Benaki icon, but it comes very close to it from the point of view of iconography. The lower part is not well preserved but it seems that in the centre, just above the dedicatory inscription, there might have been a seraph as in the Benaki icon. There is

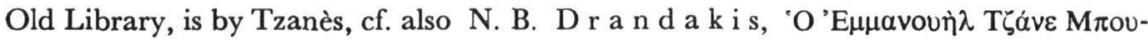

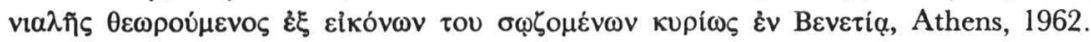

22. See also another icon in the same collection, no. $12(\Lambda 329-\Sigma . \Lambda .279)$ and one by Ieremias in Sinai, unpublished, dated 1612 .

23. The nucleus of the liturgical theophany, Christ in Glory surrounded by the symbols of the evangelists, became a component part of other, complex, compositions; among them one can distinguish post-Byzantine representations of the Last Judgement (for example, see the beautiful icon in Venice, attributed to Klotzas, $\mathrm{C} \mathrm{h}$ a t z i d a$\mathrm{k}$ i s, Icônes de Venise, no 52) in which the theme was introduced not only on account of the apocalyptic text but for liturgical reasons also.

24. Manolis Ghatzidakis e. a., Les icônes dans les collections suisses, Bern, 1968 , no 88 . 
no suggestion of a scroll with the text of the Epinikios Hymn but there can be no doubt that the icon refers to this Hymn. On stylistic grounds the icon has been ascribed to the end of the seventeenth century. Chronologically, then, it comes very close to the Benaki icon but it is not the product of the same hand. It is possible that one icon has copied the other and that the "copyist" has introduced modifications into his model. It is more likely, however, that both icons depend on another earlier icon in which the Trinity was associated with the Epinikios Hymn. In the Benaki icon the inclusion of the text of the Epinikios Hymn and the scroll motif, which as we have indicated reflects the tradition of illustrated liturgies, show that Moskos understood better the meaning of the theme; he was aware of all its liturgical connotations and declared them, as it were, in the text of the hymn. The Seraph unfolds the scroll with both hands and displays the hymn as if inviting the onlooker to participate in the singing of the "Hymn of Triumph" addressed to the Blessed Trinity.

Greek icon painters continue to represent the New Testament Trinity. But representations of the Trinity in Glory with the Four Apocalyptic Creatures are not common ${ }^{25}$. One must go to Russian icons to see the Trinity within a Majestas composition, and one must study the various influences which shaped the mystic, didactic, Russian icons to understand the meaning of compositions depicting the Trinity "seated on the throne of Glory", such as the Sestodnev and The Celestial Thro${ }^{2}{ }^{26}$. The Benaki icon, therefore, occupies a very special, important place in the world of post-Byzantine icon painting.

The liturgical Majestas in the context of the Eucharistic prayer, the Consecration, the Deesis and the Communion are all found in another significant icon in the Benaki Museum, icon inv. no. 2999. The theological ideas of this icon are rich while the discussion of its iconographic elements leads us into the realm of Italian art. The icon deserves a special consideration and we hope to return to it in a separate study.

GEORGE GALAVARIS

25. Occasionally the Trinity with the Four Zodia appears in larger compositions, as for example, in an unpublished icon of All Saints from the year 1753, in Sinai, now in the Old Library.

26. See $\mathrm{He}$ in z S k robucha ed., Ikonen, Haus der Kunst München (Exhibition Catalogue), Munich, 1969, no. 257; R o b e r t R o o z e m o n d, Ikonen - 7, Catalogue, De Wijenburgh, Echteld, 1979, no 38. In the superb collection of icons at Echteld there are important examples of this iconography which show an uninterrupted continuity, see Roozemond-van Ginhoven, op. cit.no 80. 


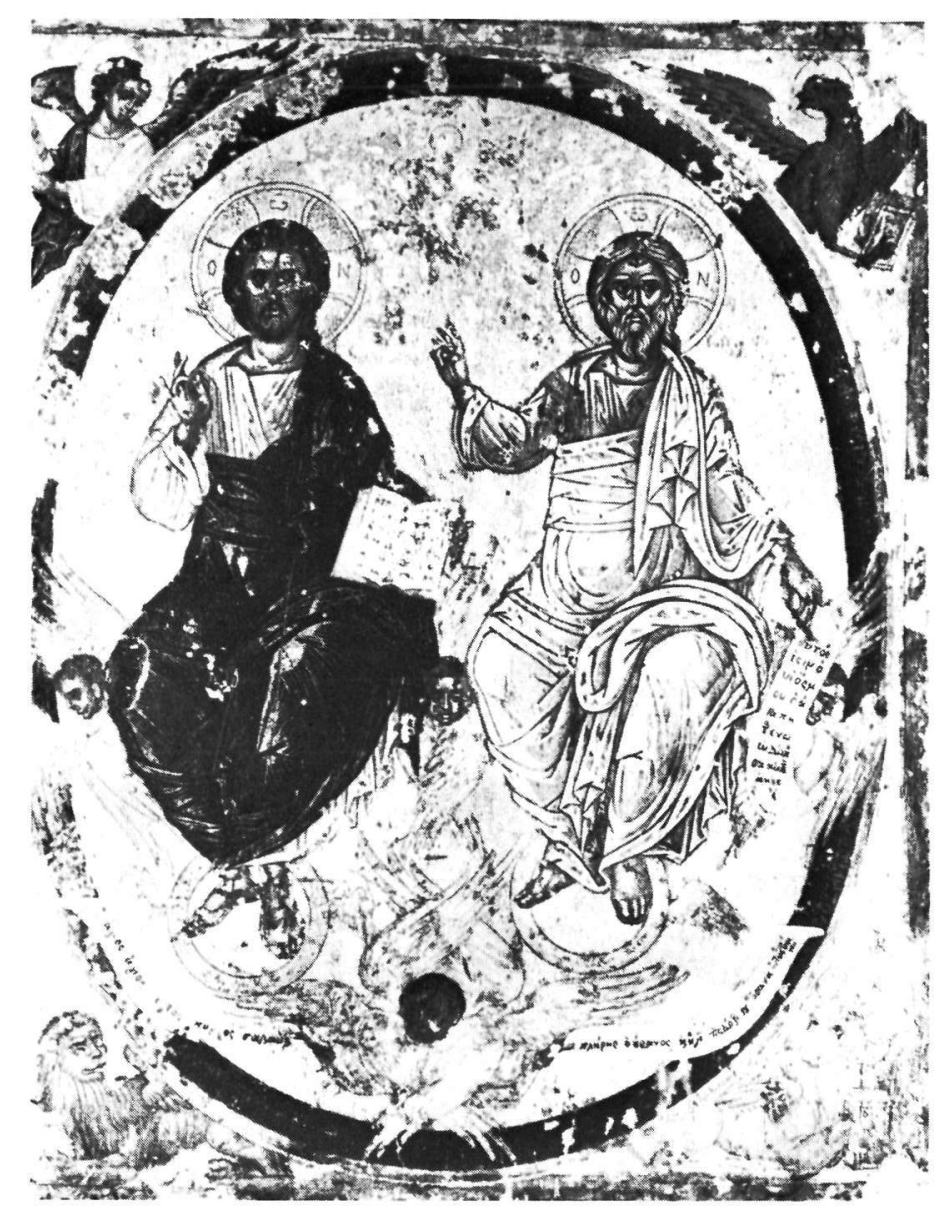

a. Ioannis Moscos, The «Epinikios Hymn,» 1702. Benaki Museum, Athens (photo courtesy of the Benaki Museum). b. The «Epinikios Hymn», end 17th century. Coll. Dr. S. Amberg-Herzog, Kölliken, Switzerland (photo after «Les icônes suisses»)

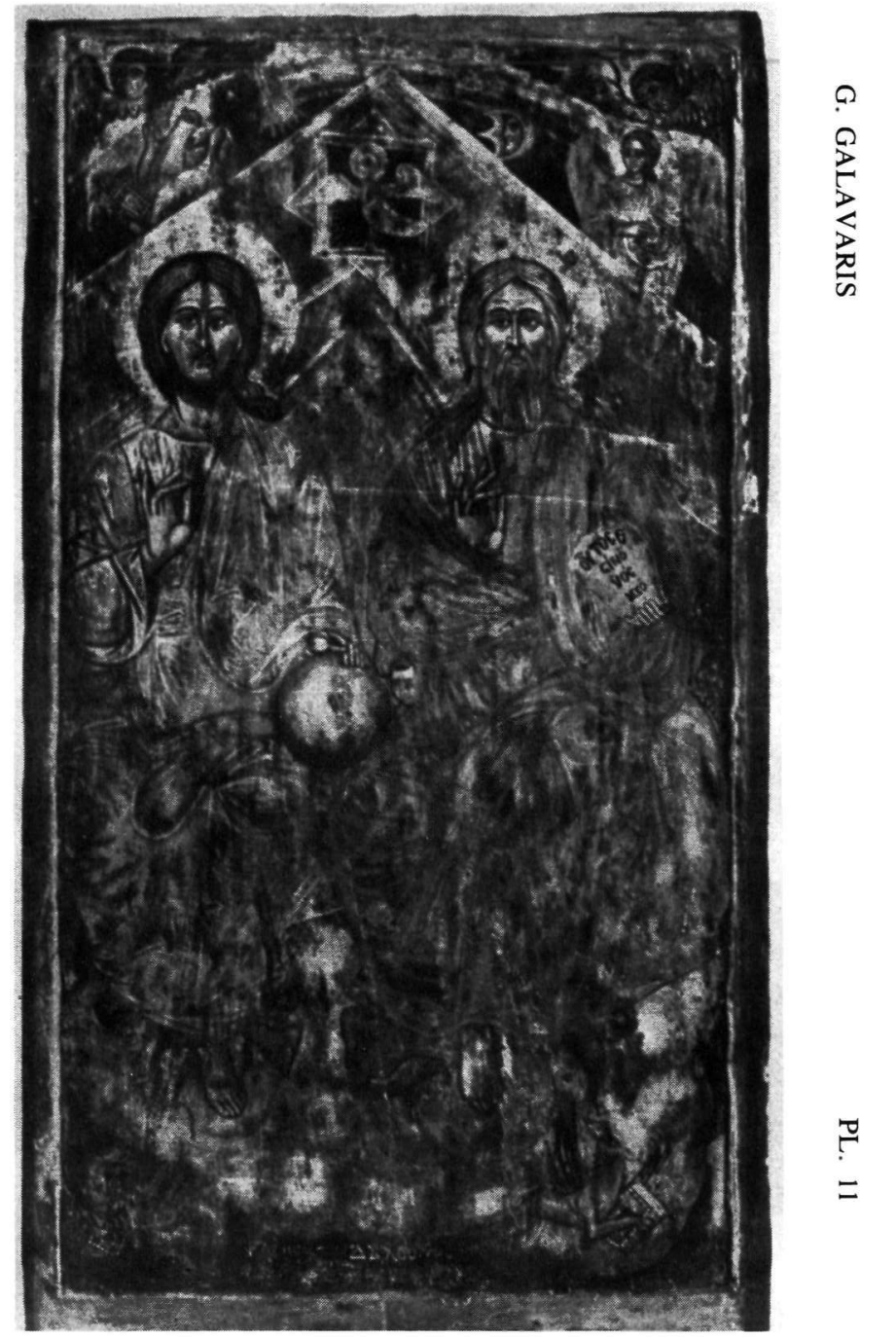



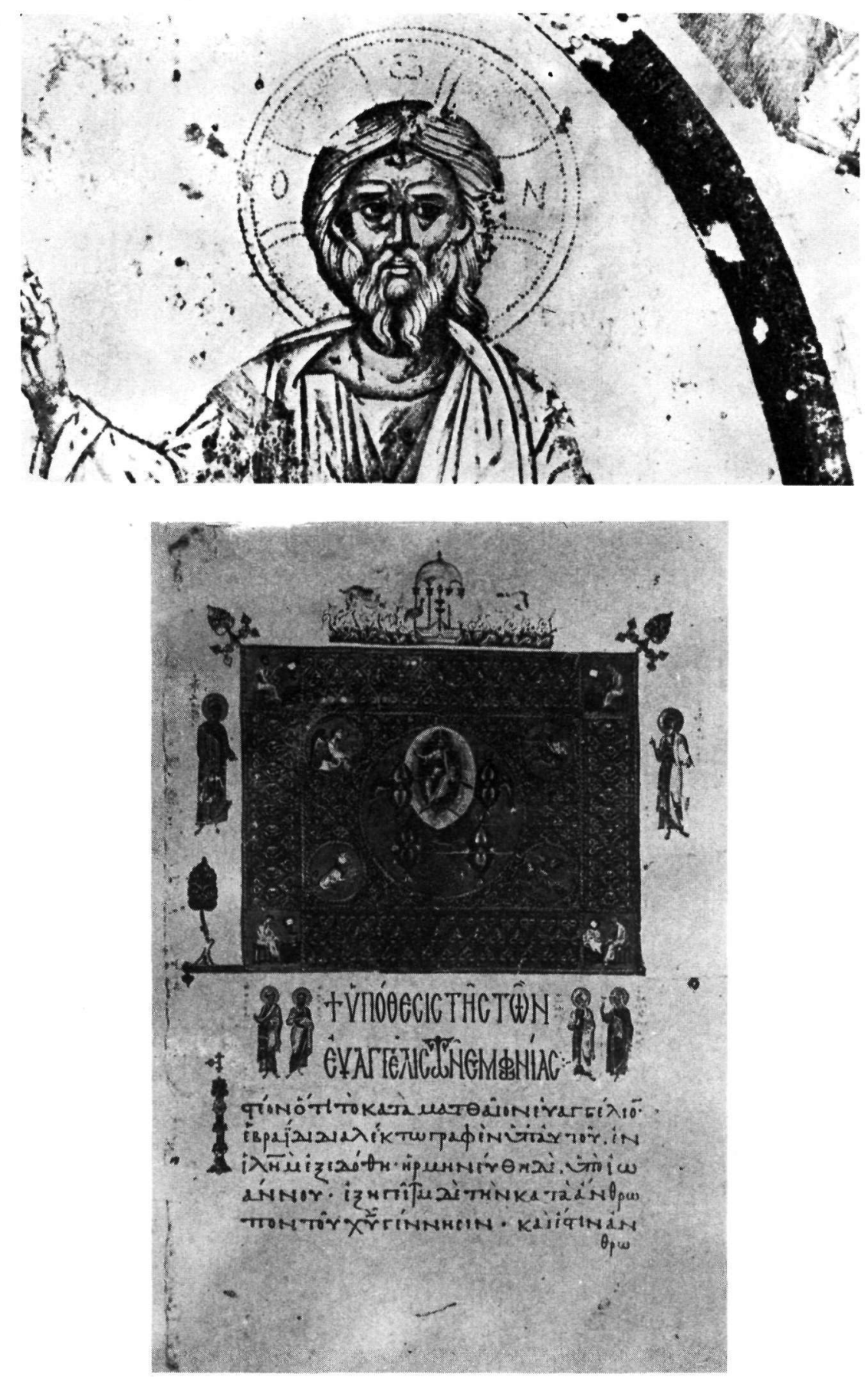

a. Detail of Pl. 11a. b. "Liturgical Theophany», cod. Parma, Pal. 5, fol. 5r. 